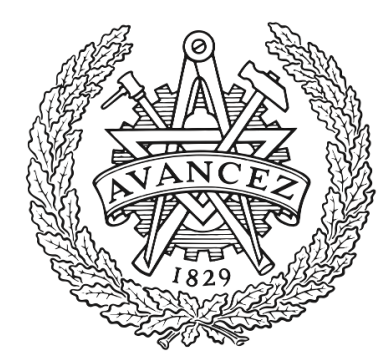

\title{
CHALMERS
}

UNIVERSITY OF TECHNOLOGY

\section{The Italian Arctic expedition 1899-1900: What happened to the first support party?}

Downloaded from: https://research.chalmers.se, 2023-04-26 02:49 UTC

Citation for the original published paper (version of record):

Lantz, B. (2021). The Italian Arctic expedition 1899-1900: What happened to the first support party?

Polar Record, 57(3). http://dx.doi.org/10.1017/S0032247421000577

N.B. When citing this work, cite the original published paper. 
Polar Record

www.cambridge.org/pol

\section{Research Article}

Cite this article: Lantz B. The Italian Arctic expedition 1899-1900: What happened to the first support party? Polar Record 57(e36): 1-9. https://doi.org/10.1017/S0032247421000577

Received: 18 July 2021

Revised: 23 August 2021

Accepted: 26 August 2021

\section{Keywords:}

Arctic exploration; Arctic ice drift; Italian Arctic expedition; Luigi Amedeo di Savoia; Umberto Cagni

\section{Author for correspondence:}

Björn Lantz, Email: bjorn.lantz@chalmers.se

This research received no specific grant from any funding agency, commercial or not-forprofit sectors.

\section{The Italian Arctic expedition 1899-1900: What happened to the first support party?}

\author{
Björn Lantz (1)
}

Technology Management and Economics, Chalmers University of Technology, 41296 Gothenburg, Sweden

\section{Abstract}

Beginning in the seventeenth century, numerous attempts were made to reach a very high latitude or even the North Pole. One of the more successful of these was the Italian Arctic expedition of 1899-1900, led by Luigi Amedeo di Savoia (Duke of the Abruzzi). Using two successively returning support parties, di Savoia's second-in-command, Captain Umberto Cagni's party eventually reached $86^{\circ} 34^{\prime} \mathrm{N}$ north of their base in the Franz Josef Land archipelago before retreating due to lack of supplies. The second support party also returned safely to the base from $83^{\circ} 16^{\prime} \mathrm{N}$. However, the first support party, led by Lieutenant Francesco Querini, disappeared without a trace after returning southwards from $82^{\circ} 32^{\prime} \mathrm{N}$. Although previous studies have cited starvation from lack of food supplies or accidents as the potential causes of their disappearance, the extant literature does not provide any deeper analyses to explain these events. This study explores the hypothesis that the first support party in fact turned back from a much more westerly position than they thought. This, in combination with an untimely blizzard that prevented travelling for several days, most likely made it impossible for Querini and his two men to return to base before their limited supplies ran out.

\section{Introduction}

Considering the long history of Arctic explorations since the fifteenth century, the expedition led by William E. Parry to Spitsbergen by the Norwegian Royal Navy in 1827 was the first organised polar sledging expedition with a serious aim of reaching the farthest northern point over the Arctic pack ice ever attempted. Parry used man-hauled 'boat sledges' to reach $82^{\circ} 45^{\prime} \mathrm{N}$ north of the Seven Islands in the Svalbard archipelago (Parry, 1828). The record stood for almost 50 years until Albert Hastings Markham reached $83^{\circ} 20^{\prime} \mathrm{N}$ in Lincoln Sea to the north of Canada's Ellesmere Island (Nares, 1878). Markham, under the leadership of George Strong Nares, used the same logistical approach as Parry. A few years later, Americans James Lockwood and David Brainard, from the Adolphus Greely-led Lady Franklin Bay Expedition (1881-1884), travelled with dog sledges along the west coast of Greenland in 1882 and eventually reached $83^{\circ} 24^{\prime} \mathrm{N}$ before being forced to return (Greely, 1886). This record stood until Norwegians Fridtjof Nansen and Hjalmar Johansen made a northwards dash in 1895 from Nansen's ship Fram, drifting across a solidly frozen Arctic basin. Nansen and Johansen reached $86^{\circ} 14^{\prime} \mathrm{N}$ on skis using dog sledges before the harsh icy conditions forced their retreat (Nansen, 1897). Towards the end of the century, a new record in reaching the northernmost point in the Arctic was created by Umberto Cagni, the second-in-command of the Italian Arctic Expedition of 1899-1900 and led by Luigi Amedeo di Savoia, the Duke of the Abruzzi. This record was created before Frederick A. Cook's mendacious claim of reaching the North Pole with two Inuit men in 1908 (Cook, 1913; Henderson, 2005); and ignores Robert E. Peary's impossible claim of having reached $87^{\circ} 06^{\prime} \mathrm{N}$ during his 1905-1906 expedition (see Herbert, 1989). Before Cagni's final dash, two of his supporting parties had already turned back. Hence, Cagni used a similar logistical approach as Captain Robert F. Scott during his march up the Beardmore Glacier towards the South Pole in December 1911. Using dog sledges, Cagni's expedition team travelled north of the Franz Josef Land archipelago to reach $86^{\circ} 34^{\prime} \mathrm{N}$ on 25 April 1900, before returning due to lack of supplies (Cagni, 1903).

These Arctic expeditions involved horrific weather conditions and dangers amidst (c) The Author(s), 2021. Published by Cambridge University Press. This is an Open Access article, distributed under the terms of the Creative Commons Attribution licence (http:// creativecommons.org/licenses/by/4.0/), which permits unrestricted re-use, distribution, and reproduction in any medium, provided the original work is properly cited.

\section{CAMBRIDGE} UNIVERSITY PRESS harsh polar winters with inadequate food and shelter, and unsophisticated equipment. Surprisingly, most members of these expeditions managed to return alive despite these conditions; however, some did not. For example, most of Greely's crewmembers, including Lockwood, perished in camp from starvation, hypothermia, and drowning during the winter of 1883-1884 (Greely, 1886). This paper focusses on the first returning three-member support party from the 1899-1900 Italian Arctic expedition, led by Lieutenant Francesco Querini, that were lost in the field (di Savoia, 1903). Because this support party literally disappeared without a trace, it is impossible to know for a fact what happened to them. In his later expedition narrative, di Savoia simply assumed that 'some accidental mishap' must have occurred (di Savoia, 1903, p.346). After realising that Querini's group had gone 
missing, he considered whether and where exactly he should send a search party. Finally, deciding to send a party eastward from his base camp in Teplitz Bay on Prince Rudolf Island, despite assuming (correctly, as it turned out) that they would not be able to find anything (di Savoia, 1903, p.248).

To the best of my knowledge, the extant literature does not contain studies attempting to cast further light on the disappearance of Querini and his two crewmembers. In his 1913 review of the then recent race to the poles, Logan Marshall recalled the incident almost poetically:

How, or when, or where, they had met their end, no one could form any opinion. A break in the ice may have precipitated them into a channel; cold may have overcome them as they slept; moving hummocks may have overwhelmed them, or a sudden snow-storm may have caused them to lose their direction, and have led them into dangers they were not able to escape. When no trace could be found of them, and no vestige of their outfit discovered on the ice, or the islands, there was only one thing the survivors could realize, and that was that their comrades had gone out of the world in silence, in mystery and in sacrifice to the knowledge of humanity. (Marshall, 1913, p.312)

Marshall was correct in the sense that their disappearance has various possible causes. The hypothesis that Querini's party probably starved to death during their return journey has been proposed by some previous authors (e.g. Albanov, 2000; Bryce, 1910; Fiala, 1906), albeit on a speculative level without any supporting analysis. Indeed, without any physical evidence, it is impossible to deduce with complete certainty what happened to Querini's party.

One approach to gain a better understanding of historical polar expedition outcomes is to use more modern scientific approaches. For example, Stroud (1987) showed through the application of modern nutritional science that an inadequate diet was the most likely factor in Captain Robert Falcon Scott's demise during his return march from the South Pole in the Terra Nova expedition of 1912. Lantz (2018) also showed through the application of optimization algorithms that Scott's depot strategy for the southwards journey from the Beardmore glacier during Terra Nova expedition was far from optimal in terms of the distance that the last party could reach based on their total consumption of supplies.

This study aimed to analyse the weather experiences of the expedition party members of the Italian Arctic Expedition of 1899-1900 by considering modern scientific knowledge about Arctic ice drift to shed light on the loss of the first returning support party. The crewmembers' personal accounts of their journey were also used along with secondary data to analyse their prior knowledge of the geographical conditions of the Arctic before undertaking their journey.

The remainder of this paper is organised as follows. First, contemporary knowledge about Arctic ice drift and its causes are summarised. Second, the 1899-1900 Italian Arctic Expedition is briefly reviewed. Finally, the narratives by expedition members Cagni and Cavalli Molinelli are analysed to provide a conclusion.

\section{The Arctic ice drift}

Ice was the primary physical obstacle for early explorers attempting to reach the North Pole or its vicinity. The presence of ice often blocked the northwards progress of ships towards the pole. Furthermore, when attempting to sledge over the ice, ice drifts often moved the expeditions in undesirable directions. The first systematic observations on ice drift were probably made by William E. Parry. During his attempt to reach the North Pole in 1827, Parry was highly frustrated with the southerly movement of the ice in his northwards
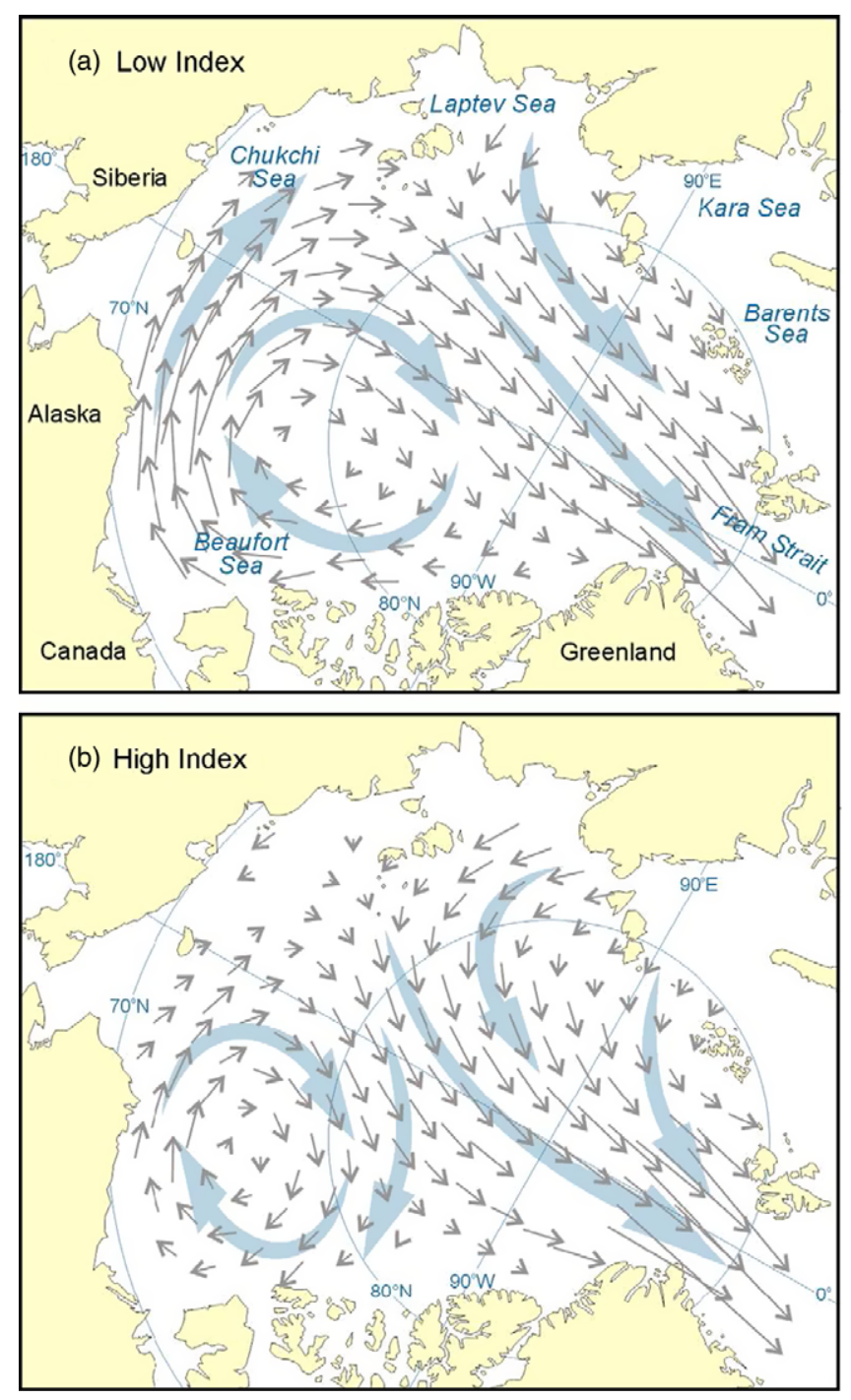

Fig. 1. Components of Arctic ice drift patterns: Beaufort Gyre and the transpolar drift stream. Source: Macdonald et al. (2005, p.26)

journey from Svalbard (Parry, 1828). He also noticed a westerly element in the ice drift (e.g. Parry, 1828, p.107), but as it did not directly interfere with his desire to reach further north, he did not mention it nearly as frequently in his narrative. Arctic ice drift also threatened other early polar expeditions. For example, it was the main reason why the engineer S. A. Andrée and his men perished during the attempted return march over the ice after a failed attempt to reach the North Pole in a hydrogen balloon in 1897 (Lantz, 2019).

Contemporary scientific studies have established two primary components of an Arctic ice drift pattern (Macdonald, Hammer, \& Fyfe, 2005). The first is a clockwise circulation in the Beaufort Sea, north of Alaska (when viewed from above the North Pole) called the Beaufort Gyre. The second component is the Transpolar Drift Stream, which is a direct movement of sea ice from the Laptev Sea north of Siberia towards the Eurasian Basin, exiting into the North Atlantic between Svalbard and Greenland (see Fig. 1). The general pattern shows slight yearly variations between the anticyclonic (strong clockwise winds over the Beaufort Gyre region caused by high atmospheric pressure; labelled 'Low Index' in Fig. 1) and cyclonic conditions (the opposite atmospheric conditions; labelled 'High Index' in Fig. 1). 
The Transpolar Drift Stream was a prerequisite for Fridtjof Nansen's successful drift across the Arctic basin in Fram in 1893-1896. The Norwegian meteorologist and professor Henrik Mohn (see Mohn, 1887) was the first to hypothesise this ice drift pattern based on the discovery of the debris of the Jeannette on the southwest coast of Greenland several years after the ship's wreckage in 1881 on the ice off the north Siberian coast (Lytzen, 1885). Trusting Mohn's analysis, Nansen decided to take advantage of this drift pattern in his ensuing Fram expedition (Nansen, 1893). Although Nansen still believed in 1893 that sea currents were the primary propellers of ice across the polar basin, he (correctly) deduced, based on his experiences during the expedition, that the wind in fact was the main determinant of the Arctic ice drift. He also correctly noted that the ice tended to drift somewhat to the right of the prevailing wind direction due to the Coriolis force (Nansen, 1902).

Given this study's aim, di Savoia and his crew's knowledge about the Arctic ice drift is critical to analysing their expedition strategy. Before embarking on the 1899-1900 expedition, di Savoia had thoroughly discussed his plans with Nansen, who had recently returned from his Fram expedition. Therefore, the Italians were aware of the long-term westerly element of the ice drift in the area from where they would venture towards the North Pole (di Savoia, 1903). To offset the ice drift, Cagni tried to hold a general true NNE course (i.e. he marched towards the magnetic north) during his outwards march over the ice (Cagni, 1903). He also advised Querini and Cavalli Molinelli to trend towards the southeast during their respective return southwards marches (di Savoia \& Cagni, 1901). However, it is unclear whether di Savoia or Cagni realised the strength of the short-term relationship between the wind and ice drift.

Scientific knowledge about the causes of Arctic ice drift has dramatically improved over time (e.g. Macdonald et al., 2005; Spreen, Kwok, \& Menemenlis, 2011; Uotila, 2001). We know now that the direction and speed of the wind accounts for almost $70 \%$ of the short-term sea ice motion, which explains how the ice drifts on a daily to weekly basis (National Snow and Ice Data Center, 2020). Hence, taken together, all other explanatory factors of ice drift (e.g. currents, tides and the thickness of the ice) have less than half the explanatory power of wind. In addition, this correlation seems stronger for the Transpolar Drift Stream than for the Beaufort Gyre (Kimura \& Wakatsuchi, 2000). Hence, wind observation seems to be a particularly reliable method of estimating the ice drift to north of Franz Josef Land. This strong relationship between wind and sea ice drift presents a useful rule of thumb: sea ice that drifts freely moves at approximately $2 \%$ of the wind speed, slightly less when the ice is smooth/thick and slightly more when the ice is rough/thin, and approximately $30^{\circ}$ to the right of the wind direction (National Snow and Ice Data Center, 2020). Thus, if the average wind speed is $10 \mathrm{~m} / \mathrm{s}$ during a 24 hour period, Arctic ice can be expected to drift at a speed of approximately 0.2 $\mathrm{m} / \mathrm{s}$ during the same period, moving the ice in the area by approximately $15-20 \mathrm{~km}$ somewhat to the right of the wind direction. Some older studies also suggest that in the past, the sea ice may in the Arctic may have been slightly less responsive to wind, perhaps closer to $1 \%$ than the $2 \%$ mentioned above (Tschudi, Meier, \& Stewart, 2020).

\section{Review of the Italian expedition}

Despite being only 25 years old, Luigi Amedeo di Savoia, the Duke of the Abruzzi, was already an experienced mountaineer and explorer when he outlined his Polar expedition plan in 1898.
With the knowledge of the methods used in previous successful long-distance Arctic sledge journeys made by, for example, Wrangell, Peary, and Nansen, he ordered 120 Siberian dogs and travelled to Norway to purchase a suitable ship (di Savoia, 1903, p.21). Jason was the best available ship at the time (the same ship used by Nansen in his 1888 expedition to Greenland), which di Savoia substantially upgraded and renamed Stella Polare-the Pole star (di Savoia, 1903, p.24). Before the expedition, di Savoia held several meetings with Nansen, who advised him regarding logistics, equipment, and other aspects of the expedition based on his experiences from the recent Fram expedition (di Savoia, 1903, pp.39-40). Di Savoia's overall plan was to sail as far north as possible through the Franz Josef Land archipelago, spend the winter at a suitable location, and then travel northwards over the ice using dog sledges to reach the highest possible latitude or perhaps even the North Pole itself (di Savoia, 1903, p.vii).

The expedition crew comprised 11 Italian and 9 Norwegian crewmembers when leaving Archangel on 13 July 1899, before steaming north towards Franz Josef Land (di Savoia, 1903, p.49). After visiting Frederick Jackson's base camp at Cape Flora, they tried to force their way northwards through Nightingale Sound, but the ice forced them to retreat (di Savoia, 1903, p.67). Di Savoia decided to attempt reaching the Queen Victoria Sea through a route west of Franz Josef Land, but the ice prevented them from reaching Alexandra Land. He then chose to return to Nightingale Sound and could eventually penetrate the ice there (di Savoia, 1903, p.84).

On 6 August, during their northwards journey into open water through the British Channel, they encountered a sealing ship called Capella close to Eaton Island. This ship had the American explorer Walter Wellman with his crew on board, who were returning home after a failed attempt to reach the North Pole from Franz Josef Land. The crews socialised for a while on Stella Polare before their ships continued in opposite directions (di Savoia, 1903, p.86). Captain Olaf Støkken of Capella did not know that this would be the last time he saw his son, Henrik Alfred Støkken, the engineer of Stella Polare who disappeared with Querini and Ollier during the detachment's return from the Italian sledge journey.

Eventually, the expedition reached Prince Rudolf Island on 8 August with relative ease-the ice conditions were unusually favourable (di Savoia, 1903, p.90). Figure 2 shows the route to the Prince Rudolf Island through the archipelago. The visibility on the day of their arrival was perfect. Therefore, di Savoia could immediately reject the existence of Petermann Land to the north and King Oscar Land to the west (di Savoia, 1903, p.96), both of which Julius von Payer had mentioned sighting on a misty day during his sledge journey through Franz Joseph Land 25 years before (Payer, 1876). Di Savoia's crew anchored at Teplitz Bay, the northernmost bay of Prince Rudolf Island's western coast at approximately $81^{\circ} 47^{\prime} \mathrm{N} 58^{\circ} \mathrm{E}$, with the idea of spending the winter there. However, when the ice pressure severely damaged the ship, they had to establish a permanent tent-based camp ashore on the nearby beach (di Savoia, 1903, p.130).

After spending the first part of the winter in relative tranquillity, the crew began preparations for the northwards journey. The food rations resembled those used in Greely's expedition but with a larger proportion of carbohydrates and a slightly smaller proportion of protein. In terms of weight, the daily ration per crewmember was almost $20 \%$ larger than that used by Greely's crew (di Savoia, 1903, p.180). Some equipment, such as sledges and kayaks, were similar to those used by Nansen a few years before, but in other cases, such as the tents, di Savoia relied on his own experience (di Savoia, 1903, pp.182-187). 


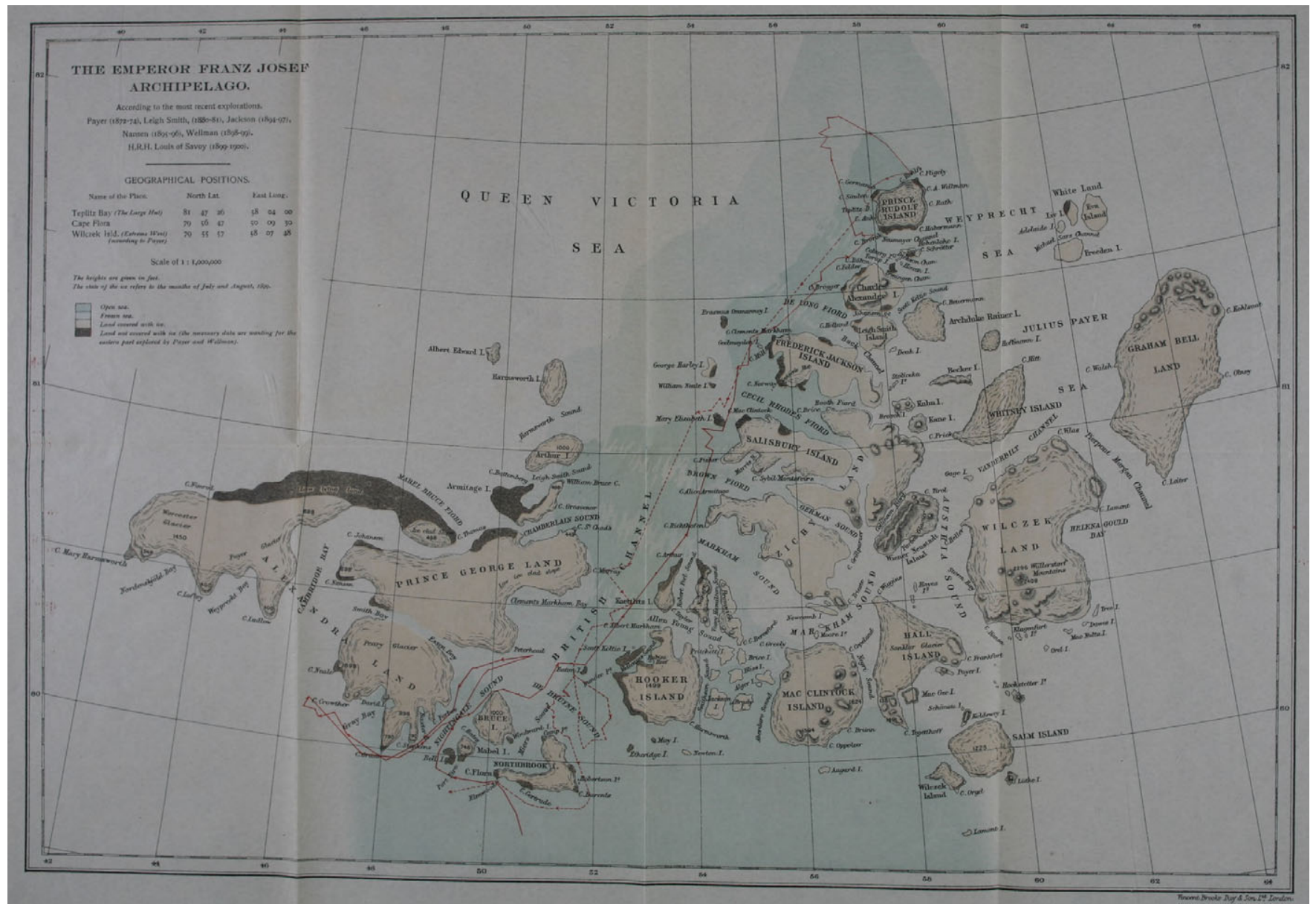

Fig. 2. Stella Polare's route towards Prince Rudolf Island. Source: di Savoia (1903)

As a result of a winter excursion, di Savoia had to amputate parts of his two fingers due to frostbite. This made him unfit to lead the sledge journey towards the pole. Thus, Captain Umberto Cagni was assigned the command of the northern march instead (di Savoia, 1903, p.190). Cagni was the obvious choice, not only because he was second-in-command but also because he was tough as nails and extremely loyal to di Savoia. The northern party set out on 20 February 1900, which proved to be too early in the season. Consequently, they were forced to retreat after a few days because of the intense cold, similar to Amundsen during his Antarctic expedition in 1911. Three weeks later, on 11 March, Cagni set out again, straight out on the pack ice from Prince Rudolf Island, with 9 crewmembers (all Italians, except the Norwegian engineer Støkken), 13 sledges, and 102 dogs as his main party (di Savoia, 1903, pp.211-212). Three Norwegians provided additional assistance during the first two days.

The overall logistical plan was as follows: a three-member detachment would first return after approximately two weeks with a sledge, a few dogs, and with just enough supplies that would enable them to return to the base. A second detachment would return after another two weeks in a similar manner (Cagni, 1903, p.350). This would leave the final three-member party with optimal conditions for their northwards journey. Because they knew they would be travelling on moving ice all the time, depot laying was not an option; all supplies needed to be brought along the sledges.
Cagni decided each returning group's composition after observing the team members' performance member during the marchthe general idea was that the least fit members would comprise the returning detachments. Cagni's plan was largely implemented after a tenth member, Støkken, was added to the crew before the departure (Cagni, 1903, p. 392). Støkken would join the first returning party, and after another team member was transferred from the first returning detachment to the final group (Cagni, 1903, p.394). The first detachment (Lieutenant Francesco Querini with Støkken and alpine guide Felice Ollier) returned from $82^{\circ} 32^{\prime} \mathrm{N}$ on 23 March with 10 days' supplies (Cagni, 1903, p. 612; di Savoia, 1903, p.245). The second detachment (Dr Achille Cavalli Molinelli with the sailor Giacomo Cardenti and alpine guide Cipriano Savoie) returned from $83^{\circ} 16^{\prime} \mathrm{N}$ on 31 March with 18 days' supplies (Cagni, 1903, p. 612; di Savoia, 1903, p.245). The reason for sending the support parties back somewhat earlier than originally scheduled was to save rations for the extra man in the final group (Cagni, 1903, p.419). The final party (Cagni with the sailor Simone Canepa and alpine guides Giuseppe Petigax and Alessio Fenoillet) continued northwards and covered substantial daily distances on relatively plain ice, after which they were eventually forced to return from $86^{\circ} 34^{\prime} \mathrm{N}$ on 25 April due to lack of supplies (di Savoia, 1903, p.345). Cagni's party returned to the base on 23 June after a horrific struggle against the westerly ice drift. Querini's detachment did not return and disappeared without a trace, and Cavalli Molinelli's group returned to Prince Rudolf Island on 18 April. Figure 3 shows the route reported by Cagni (1903). 


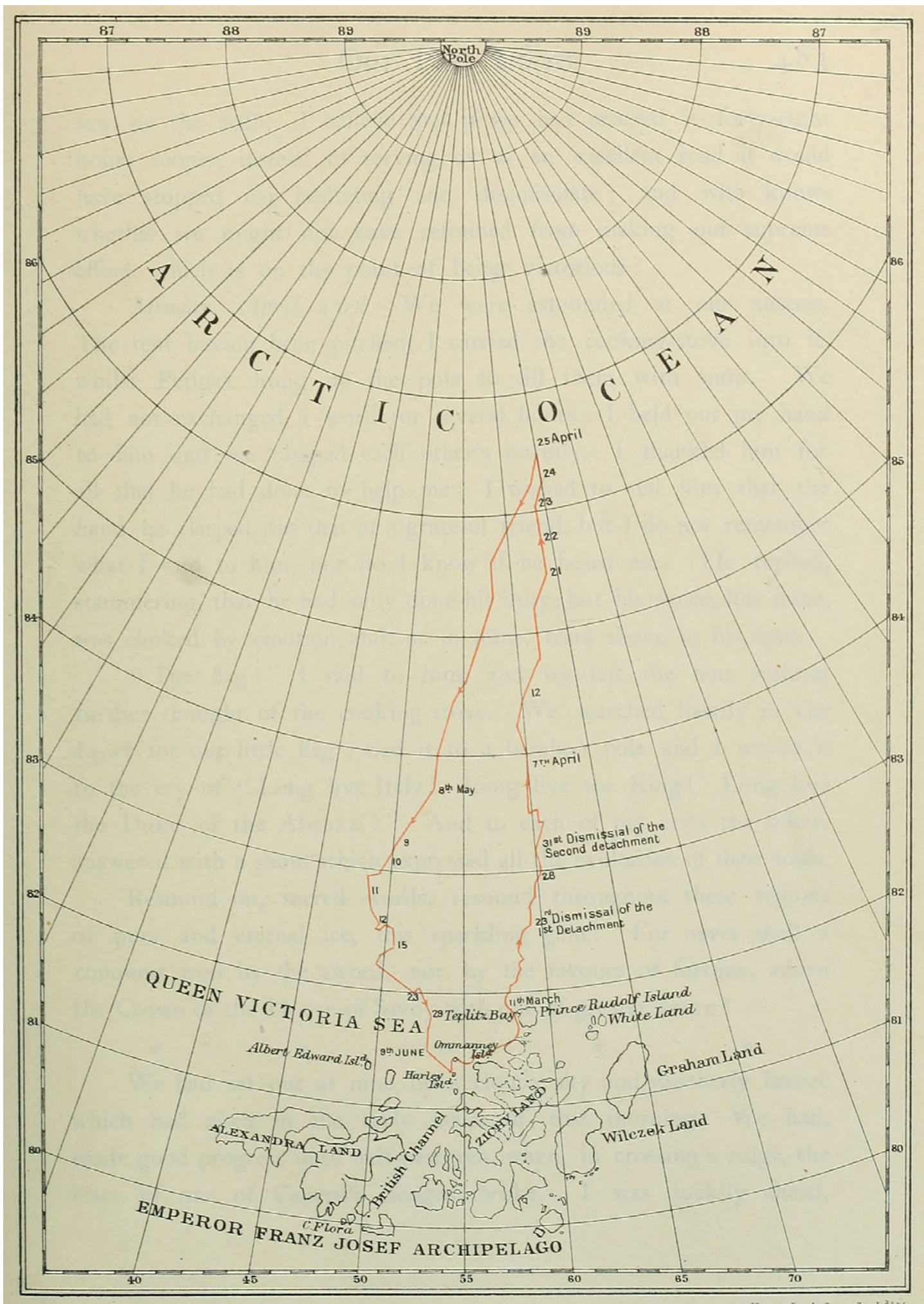

Fig. 3. Captain Cagni's northern sledge journey route. Source: Cagni (1903)

After Cagni's return to Prince Rudolf Island, di Savoia immediately began preparing for the expedition's return journey. Stella Polare was repaired and extricated from ice using explosives (di Savoia, 1903, p.304). On 16 August, they sailed away from Teplitz Bay (di Savoia, 1903, p.321). At this time, di Savoia still had a faint hope that the missing detachment might have ended up at Cape Flora, the only known provisions depot in Frans Josef Land (di Savoia, 1903, p.340). Upon reaching Cape Flora two weeks later, they found no trace of Querini and team. Stella Polare eventually reached Tromsø in Norway on 6 September 
without any major events en route. Despite their failure to reach the North Pole and the loss of three team members, the expedition garnered international attention both for di Savoia and Italy (Cauli, 2019).

\section{Analysis}

The expedition team departed from Teplitz Bay on the morning of 11 July, straight out on the ice. The first week's marches covered an average daily distance of approximately 7 geographical miles $(13 \mathrm{~km})$, which was good but not impressive in comparison to other expeditions at the time. As mentioned earlier, Cagni and his team generally marched towards the magnetic north (Cagni, 1903:404) on their outwards journey, effectively travelling approximately in a NNE direction over the ice, because the magnetic declination at the time was slightly above $20^{\circ} \mathrm{E}$ (Thébault et al., 2015). The idea was to compensate for the long-term westerly ice drift that Cagni knew they would be exposed to, based on the mean drift experienced by Fram (Cagni, 1903, p.404).

Somewhat surprisingly, Cagni did not seem to have observed his longitude during the northern journey until reaching his farthest north camp, located at $86^{\circ} 34^{\prime} \mathrm{N}$ and $64^{\circ} 30^{\prime} \mathrm{E}$, which was slightly to the east of Prince Rudolf Island and 20 geographical miles $(37 \mathrm{~km})$ farther north than Nansen's prior record. His narrative from the outward journey imply, somewhat surprisingly, that he was not too worried about being unable to determine his longitude for a long time. One reason for this may be that Cagni was unaware of the rather frequent short-term variations in the expected westerly ice drift in the area. In addition, Cagni was mostly concerned about the latitude during the northwards journey, under the assumption that his general rule of thumb of maintaining an approximate NNE direction would be satisfactory to offset the long-term westerly ice drift in the area. He only needed precise longitudinal measurements in his return march to reach the base camp on Rudolf Island. Hence, Cagni made several longitudinal observations during the latter part of his southwards journey.

After the first week of the northwards march, Cagni's crew faced three days of continual and strong approximately easterly winds during 18-20 March (Cagni, 1903, pp.414-419), when a storm was followed by a fresh breeze. A storm typically has a wind speed of approximately $30 \mathrm{~m} / \mathrm{s}$, whereas a fresh breeze has a wind speed of approximately $10 \mathrm{~m} / \mathrm{s}$ (Smyth, Jackson, \& Cooper, 2013). Hence, the average wind speed during the three days of strong and continual approximately easterly winds was probably close to $20 \mathrm{~m} / \mathrm{s}$. The general assumption that sea ice moves at $2 \%$ of the wind speed indicates that the approximate drift speed at the time was approximately $0.4 \mathrm{~m} / \mathrm{s}$ or 19 geographical miles $(35 \mathrm{~km})$ per day. Thus, a rough but reasonable estimation is that the strong easterly winds during those three days moved Cagni and his crew approximately $55-60$ geographical miles $(102-111 \mathrm{~km})$ in a westerly direction. However, as mentioned earlier, the Arctic Sea ice was probably slightly less responsive to the wind during the time of the Italian expedition than at present. Therefore, by conservative estimates, the westwards shift of the ice during 18-20 March 1900 may have been slightly less, perhaps 30-35 geographical miles (56$65 \mathrm{~km}$ ). In any case, the crew was likely much further to the west on the 21 March than they were aware of at the time.

A similar wind-based drift struck Robert E. Peary's expedition during his attempt to reach the North Pole from Ellesmere Island in the Canadian Arctic in 1906. During six days of continuous westerly gale that was strong enough to prevent travel, their ice floe drifted eastwards by approximately 70 geographical miles (130 $\mathrm{km}$ ), while Peary and his crew were stuck in their camp slightly north of $85^{\circ} \mathrm{N}$ ('Pearys own story of his farthest north dash', 1906). Unlike the Italians six years earlier, Peary could observe his longitude both before and immediately after the gale, giving him sufficient idea of what had happened to eventually choose another route back south.

After the third day of the outwards march, Cagni no longer reported the bearings of the capes on Prince Rudolf Island in his narrative. In fact, his narrative does not mention anything about southwards views until 21 March, when he supposedly sighted the outline of Prince Rudolf Island to their south (Cagni, 1903, p.420). Cavalli Molinelli (1903, p.644) also mentioned this sighting in his narrative. However, given the Earth's curvature, Prince Rudolf Island would not have been visible at the distance covered so far. A formula for calculating the distance to the visible horizon $D$ for a spectator at a height $h$ above the earth's surface, disregarding atmospheric refraction, is $D=\left(2 \times R \times h+h^{2}\right)^{1 / 2}$, where $R$ represents the earth's radius (Lynch, 2008). If $R \approx 6370 \mathrm{~km}$ and the height $h=0.461 \mathrm{~km}$ (the highest elevation on Prince Rudolf Island), the distance to the horizon for a person standing at highest point on Prince Rudolf Island is $D=(2 \times 6370 \times 0.461+$ $\left.0.461^{2}\right)^{1 / 2}=76,6 \mathrm{~km}$, which corresponds with approximately 41 geographical miles. Under standard atmospheric conditions, the effect of refraction increases the distance to the visible horizon by up to $9 \%$ (Vollmer, 2020), which implies that from a distance of 45 geographical miles $(83 \mathrm{~km})$ or above, not even the highest point of the Prince Rudolf Island would be visible, even under perfect visibility. The approximate distance between Prince Rudolf Island and Cagni's party on the ice at the time was approximately 45 geographical miles (di Savoia, 1903, p.341. Therefore, even after considering the refraction, Cagni's party could not have sighted the outline of Prince Rudolf Island to their south on 21 March, even if they had been directly to its north, because it would have been too far away and thereby below the horizon. Thus, they must have seen something else-most likely a hummock or some other sort of ice formation. It is not uncommon to envision the shapes of non-existent lands polar regions. Julius Payer's alleged sightings of Petermann Land and King Oscar Land from Prince Rudolf Island in 1874 are good examples (Payer, 1876).

Cagni decided that the first party to return would comprise Querini, Ollier, and Støkken-the last because he was not Italian and the other two for health reasons (Cagni, 1903, p.420). On the morning of $23 \mathrm{March}$, they began their return journey from $82^{\circ} 32^{\prime} \mathrm{N}$ with provisions for 10 days (di Savoia, 1903, p.245), which, at full rations, would last for two days less than the ones used to travel from their base to their current location. Hence, when they began their return march they had a negative margin for navigational errors or unforeseen events that could have prevented their journey. They were never to be seen again.

On the evening of 23 March, after the first detachment's departure, Cagni began speculating, without yet having made any longitudinal observations during their northwards march, that they might have deviated west from their course. Hence, what looked like the outline of an island to their south two days ago, might not have been Prince Rudolf Island at all (Cagni, 1903, p.424). However, Querini's party had already begun their return journey, convinced that they were on the same meridian as their base in Teplitz Bay.

Neither Querini, Ollier, and Støkken's remains nor anything in their gear have ever been found, hence, their traceless disappearance suggests that they perished on ice rather than on shore. As Querini started his journey with the idea that Prince Rudolf 
Island was directly south of him, he might have discounted Cagni's advice to trend towards the southeast to compensate for the longterm ice drift. If so, their situation was almost hopeless from the outset. To make things worse, the upcoming blizzard from 1-4 April, which impeded the second returning detachment's travel, must have forced Querini's party to remain in their tents as well, even though their supplies had almost or entirely depleted by then. In addition, Querini's party did not have a boat with them-the two boats that were brought were to be used by the second returning party and the polar party. Cavalli Molinelli's (1903, pp.650-651) narrative of the second detachment's return march noted that during that year, the spring season was exceptionally warm, with the ice around Prince Rudolf Island being broken up with many leads. Thus, even if Querini's managed to, against all odds, come close to Prince Rudolf Island before running out of supplies, they would probably have been blocked from coming ashore by open water amidst the ice. Finally, similar to Cagni during the same period of time, Cavalli Molinelli did not report having been able to make any longitudinal observations during his return march, which began from an even more northerly position than Querini's departure point. Therefore, one can reasonably assume that Querini did not make any longitudinal observations either and was most likely unaware of venturing too far to the west, until it was too late.

On 28 March, Cagni noted a latitude of $82^{\circ} 58^{\prime} \mathrm{N}$, which was 50 geographical miles $(93 \mathrm{~km})$ south of his rather conservative estimate based on dead reckoning, all due to the ice drift. He did not record any thoughts about possible shifts in the longitude at this point. In fact, on 30 March he reported his inability to determine his longitude based on solar observation since they had left Teplitz Bay. Hence, he could not have known at that point if, or how much, they had drifted off their original meridian since they last sighted Prince Rudolf Island.

The second supporting party comprising Dr Cavalli Molinelli, Savoie, and Cardenti began their return march from $83^{\circ} 16^{\prime} \mathrm{N}$ in the morning of 31 March, carrying provisions for 18 days (di Savoia, 1903 , p.245). Because they had travelled 20 days to reach that position, they too had a negative margin for navigational errors or unforeseen events. Meanwhile, Cagni continued to steer northwards with his polar party comprising Petigax, Fenoillet, Canepa, and himself. At this point, they were probably still much farther to the west than they assumed because, since 18-20 March, there were no strong winds as that could have substantially shifted the ice pack. However, the first four days of April presented continual strong winds (mostly westerly winds) with blizzard conditions that prevented travelling for both Cagni's and Cavalli Molinelli's parties. During this period, the wind likely pushed the freely drifting sea ice back to the area eastwards, at a distance similar to the westward movement due to strong easterly winds from 18-20 March. Hence, this blizzard probably contributed to save Cavalli Molinelli's party from meeting the fate of Querini's team. This is because, unbeknownst to them, the blizzard likely moved the ice underneath back to a point somewhere north of Prince Rudolf Island while they had to lay still on the ice. However, as mentioned above, this blizzard in combination with the ice drift was possibly the most likely cause of Querini, Støkken, and Ollier's disappearance, because, similar to the other two parties, the harsh weather would have prevented them from travelling further even though their supplies were running out. After this blizzard, the second returning detachment did not report any substantial problems and was finally able to reach Prince Rudolf Island on 18 April. At the time, due to the open water around the island, their boat was a fundamental instrument facilitating their rescue (Cavalli Molinelli, 1903).

Cagni's party could continue northwards, generally covering comfortable daily distances on good ice, until reaching their farthest north point at $86^{\circ} 34^{\prime} \mathrm{N}$ on April 24, before a lack of supplies forced them to return. At this point, Cagni could finally observe his longitude at $64^{\circ} 30^{\prime} \mathrm{E}$, slightly east of the Teplitz Bay. Hence, Cagni must have been highly satisfied by following his rule of thumb of treading only slightly to the east to compensate for the long-term ice drift. However, his return journey to the south presented substantial problems with the ice drift.

On 25 April, Cagni's team began their southwards journey with provisions for 30 days containing 200 rations of pemmican and 300 rations of dog food for 34 dogs (di Savoia, 1903). During their return journey, Cagni measured his longitude for the first time on 9 May and found that they were at $50^{\circ} \mathrm{E}$ and had drifted westwards by almost 60 geographical miles $(111 \mathrm{~km})$ from their farthest north. Around the end of April, when Cagni's team faced three days of strong and continual south-easterly winds, he rightly suspected that the winds could have driven them westwards (Cagni, 1903, p.507). This was evidently a serious deviation from their optimal course, partly because it prolonged the distance towards their returning point and especially because they now had to tread more pronouncedly towards the east to offset the westerly drift.

Cagni's narratives notably reported the results of his longitudinal measurements during his return journey in terms of hours, minutes, and seconds, rather than using the more common format of degrees, minutes, and seconds. This is because longitudinal sights are fundamentally dependent on the time difference between the current location and Greenwich (Bowditch, 1938). However, it is easy to translate between the hour and the degree longitude formats because there are 24 hours in a day and 360 degrees in a circle; hence, the sun appears to move across the sky at a rate of 360 / $24=15^{\circ}$ per hour. Thus, on 9 May, when Cagni measured the longitude for the first time, he observed that he was $3 \mathrm{~h}, 19 \mathrm{~min}$, and 58 s east of Greenwich, corresponding to $49.992^{\circ}$ in the decimal form, or $49^{\circ} 59^{\prime} 31^{\prime \prime} \mathrm{E}$ in the traditional sexagesimal degree format, which Cagni rounded off to an even $50^{\circ} \mathrm{E}$.

After having discovered the westwards drift, Cagni's team spent over a month trying to come back eastwards or at least to avoid being transported further to the west, often with little hope of success, as vividly documented in Cagni's narrative. They desperately needed to return to the south, while also offsetting the effects of the westerly ice drift. Three weeks later, on 29 May, they were at the same latitude as their base camp in Tepliz Bay but 50 geographical miles $(93 \mathrm{~km})$ to the west in terms of the longitude. After an extreme effort and many forced marches, they reached the shore of Ommanney Island on 13 June, approximately 30 geographical miles $(56 \mathrm{~km})$ southwest of Teplitz Bay. Ten days later they finally returned to their main camp on Prince Rudolf Island, where their friends waited despite having almost given up hope for their return.

\section{Conclusion}

It is difficult to conclude with certainty what happened to Querini, Støkken, and Ollier during their return march, due to the lack of any physical evidence. Their disappearance has several possible causes. However, as this study showed, the most likely course of events seems to be that the blizzard during 18-20 March had moved the pack ice underneath their feet much further west than they realised when they began their return journey. This, combined with the four-day blizzard in early April that prevented them from 
travelling, likely lead to death by starvation after running out of supplies and not finding their way back to the base camp.

Some studies have already suggested the hypothesis about the first returning detachment starving to death; however, such a hypothesis was generally proposed at a speculative level without any supporting analysis. For example, Fiala (1906, p.6) thought that the crew probably starved to death, simply because the harsh icy conditions prevented them from covering sufficient distances to enable them to survive on their food and fuel supplies. Albanov (2000, p.160) also claimed that they 'died of starvation along the way', without substantial support. Bryce (1910, p.268) speculated that the ice drift during their return march made it impossible for them to reach Prince Rudolf Island before running out of food. However, the idea that Querini's party's disappearance could be explained through the faulty estimation of their position because of the ice drift during the blizzard 18-20 March, causing them begin their return journey from a point much further to the west than they thought, has not yet been proposed in the extant literature.

Interestingly, di Savoia's narrative entirely evaded speculations about the fate of Querini's party. Although di Savoia clearly must have contemplated about these events during the final months in camp on Prince Rudolf Island, his narrative did not contain any reflection about it beyond a general belief about some sort of accident preventing their safe return. In fact, he even thought that it was 'useless to attempt to seek why they failed to return' (di Savoia, 1903, p.341). Perhaps a psychological approach could be used in future research to cast further light on this avoidant attitude.

After their disappearance, Støkken's father was the last known person to attempt to find the missing party or seek closure on their disappearance (Horn, 1930). In 1901, Captain Støkken led a Norwegian search expedition in the sealer Capella, travelling to Cape Flora and along the southern coasts of Franz Josef Land. However, he could not find any trace of his son and his team members.

Notably, the missing party members were appropriately honoured posthumously. For example, in 1929, a crew of the Russian steam icebreaker Sedov erected a memorial tablet in Teplitz Bay to honour Querini, Støkken, and Ollier when they visited the location (Wiese, 1929). In addition, a small island in the Franz Josef Land archipelago, just east of the cape on Jackson Island where Nansen and Johansen spent the winter of 18951896, was christened Querini Island. Two capes in southern Jackson Island were also named Cape Støkken and Cape Ollier.

Finally, even though modern scientific knowledge sometimes can be applied in relation to different historical polar expeditions in order to increase the understanding of them, it is important to note that the analyses of actual decision making during such expeditions must rely on the scientific knowledge at the time. Hence, this study should be taken primarily as an attempt to initiate further discussion and research about the reasons for the outcomes of different polar expeditions during the Heroic Age, rather than as criticism of di Savoia and his expedition.

Conflict of interest. None.

\section{References}

Albanov, V. I. (2000). In the land of white death. New York: Modern Library. Amedeo Di Savoia, L. (Duke of the Abruzzi) (1901). The Italian Arctic Expedition, 1899-1900. The Geographical Journal, 18(3), 282-284. doi: 10. $2307 / 1775135$
Amedeo Di Savoia, L. (Duke of the Abruzzi) (1903). On the Polar Star in the Arctic Sea. London: Hutchinson.

Amedeo Di Savoia, L. (Duke of the Abruzzi) \& Cagni, U. (1901). Farther North than Nansen. London: Howard Wilford Bell.

Bowditch, N. (1938). American Practical Navigator, United States Hydrographic Office.

Bryce, G. (1910). The Siege and Conquest of the North Pole. London: Gibbings \& Company Limited.

Cagni, U. (1903). Report of Commander Umberto Cagni on the Sledge Expedition Towards the Pole. In di Savoia, L. A. (Duke of the Abruzzi) (1903). On the "Polar Star" in the Arctic Sea (pp. 349-612). London: Hutchinson.

Cauli, A. (2019) The Duke of Abruzzi's noble idea of winning the North Pole for Italy: popularization of the Arctic Expedition led by Luigi Amedeo of Savoia, Terrae Incognitae, 51(2), 153-169, doi: 10.1080/00822884.2019.1633033

Cavalli Molinelli, P. A. (1903), Report of Dr. Achille Cavalli Molinelli on his Journey with Sledges while Returning from the Latitude of $83^{\circ} 16^{\prime}$ to Teplitz Bay. In di Savoia, L. A. (Duke of the Abruzzi) (1903). On the "Polar Star" in the Arctic Sea (pp. 621-663). London: Hutchinson.

Cook, F. A. (1913). My Attainment of the Pole. New York: Mitchell Kennerly. Fiala, A. (1906). Fighting the Polar Ice. New York: Doubleday, Page \& Company. Greely, A. W. (1886). Three Years of Arctic Service. New York: Charles Scribner's \& Sons.

Henderson, B. (2005). True North. New York: W. W. Norton \& Company.

Herbert, W. (1989). The Noose of Laurels: Robert E. Peary and the Race to the North Pole. New York: Atheneum Books.

Horn, G. (1930). Franz Josef Land: Natural History, Discovery, Exploration, and Hunting. Skrifter om Svalbard og Ishavet, 29. Oslo.

Kimura, N., \& Wakatsuchi, M. (2000). Relationship between sea-ice motion and geostrophic wind in the Northern Hemisphere. Geophysical Research Letters, 27(22), 3735-3738. doi: 10.1029/2000GL011495

Lantz, B. (2018). Where should Captain Scott's support parties have turned back? Polar Record, 54(1), 76-78. doi: 10.1017/S0032247418000098

Lantz, B. (2019). Ice drift during the 1897 Andrée balloon expedition. Polar Record, 55(6) 385-391. doi: 10.1017/S0032247419000706

Lynch, D. K. (2008). Visually discerning the curvature of the Earth. Applied Optics, 47(34), H39-H43. doi: 10.1364/AO.47.000H39

Lytzen, C. (1885). Levninger fra Jeanette-Expeditionen paa Grønlands Vestkyst. Geografisk Tidsskrift, Bind 8, 49-51.

Macdonald, R. W., Harner, T., \& Fyfe, J. (2005). Recent climate change in the Arctic and its impact on contaminant pathways and interpretation of temporal trend data. Science of the Total Environment, 342, 5-86. doi: 10.1016/j. scitotenv.2004.12.059

Marshall, 1. (1913). The Story of Polar Conquest. New York: L. T. Myers.

Mohn, H. (1887). Den Norske Nordhavs-Expedition 1876-1878: Nordhavets Dybder, Temperatur og Strømninger. Christiania: Grøndahl \& Søns Bogtrykkeri.

Nansen, F. (1893). How can the North Polar region be crossed? The Geographical Journal, 1(1), 1-22. doi: 10.2307/1774198

Nansen, F. (1897). Farthest North. New York: Harper and Brothers.

Nansen, F. (1902). Oceanography of the North Polar basin. The Norwegian North Polar Expedition 1893-1896. Scientific Results. Greenwood Press, New York.

Nares, G. S. (1878). A Voyage to the Polar Sea. London: Sampson Low, Marston, Searle, \& Rivington.

National Snow and Ice Data Center. (2020, 3 April). All About Sea Ice: Dynamics. https://nsidc.org/cryosphere/seaice/processes/dynamics.html

Parry, W. E. (1828). Narrative of an Attempt to reach the North Pole. London: John Murray.

Peary's own story of his farthest north dash. (1906, 2 November). The Sunday Oregonian, Portland. Page 43.

Payer, J. (1876). New Lands Within the Arctic Circle. London: MacMillan and Co.

Smyth, T. A. G., Jackson, D. W. T., \& Cooper, J. A. G. (2013). Three dimensional airflow patterns within a coastal trough-bowl blowout during fresh breeze to hurricane force winds. Aeolian Research, 9, 111-123. doi: 10. 1016/j.aeolia.2013.03.002 
Stroud M. A. (1987). Nutrition and energy balance on the 'Footsteps of Scott' expedition 1984-86. Human Nutrition. Applied Nutrition, 41(6), 426-433.

Spreen, G., Kwok, R., \& Menemenlis, D. (2011), Trends in Arctic sea ice drift and role of wind forcing: 1992-2009, Geophysical Research Letters, 38, L19501. doi: 10.1029/2011GL048970

Tschudi, M. A., Meier, W. N., \& Stewart, J. S. (2020). An enhancement to sea ice motion and age products at the National Snow and Ice Data Center (NSIDC), The Cryosphere, 14, 1519-1536. doi: 10.5194/tc-14-15192020
Thébault, E., Finlay, C.C., Beggan, C.D. et al. (2015). International Geomagnetic Reference Field: the 12th generation. Earth, Planets and Space, 67(79). doi: 10.1186/s40623-015-0228-9

Uotila, J. (2001). Observed and modelled sea-ice drift response to wind forcing in the northern Baltic Sea. Tellus, 53A, 112-128. doi: 10.1034/j.1600-0870. 2001.01172.x

Vollmer, M. (2020). Below the horizon-the physics of extreme visual ranges. Applied Optics, 59(21), F11-F19. doi: 10.1364/AO.390654

Wiese, W. (1929). Die Expedition des Eisbrechers Sedow nach Franz-Josefs Land zwecks Aufbau einer meteorologischen Radiostation. Arktis, 2(4): 124-128. 